\title{
PERKAWINAN SEJENIS DALAM PRESFEKTIF ALIRAN EKSISTENSIALISME DIKAITKAN DENGAN HAK ASASI MANUSIA
}

\author{
Otong Syuhada \\ Fakultas Hukum Universitas Majalengka \\ Jl. K.H. Abdul Halim No. 103 Majalengka Kulon, Majalengka - Jawa Barat \\ Email: otsyu130270@gmail.com
}

\begin{abstract}
Abstrak
Perkawinan pada umumnya disahkan di beberapa negara untuk pasangan yang terdiri dari satu pria dan satu wanita. Tetapi pernikahan yang serupa adalah masalah yang berbeda. Jenis pernikahan ini sering dilakukan antara pria dan wanita dan wanita. Perkawinan ini dianggap sebagai hak individu untuk membentuk hidupnya sendiri, sehingga siapa pun tidak dapat melarangnya, demikian juga aliran eksistensialisme yang menyatakan bahwa setiap individu diberi kebebasan terbesar. Tentu saja, kebebasan ini membuat seseorang melakukan hal-hal yang menurutnya benar karena berasal dari haknya sendiri sebagai individu. Dalam HAM juga disebutkan bahwa hak atas kebebasan berserikat mengandung unsur-unsur hak atas kebebasan dan hak-hak sosial dan kebebasan beragama menunjukkan hak pribadi dan kolektif yang berbeda, tetapi jika kita memeriksanya lebih dalam, jelas bahwa kebebasan yang dimaksud adalah kebebasan yang memiliki batasan yang harus dipenuhi juga; apakah itu melanggar kesusilaan, agama, atau integritas bangsa? Tujuan dari penelitian ini adalah untuk mengetahui pernikahan sesama jenis dalam aliran eksistensialisme dan untuk mengetahui perspektif hak asasi manusia dalam mengkritik pernikahan sesama jenis. Penelitian ini menggunakan pendekatan yuridis normatif dan sifat penelitian ini adalah deskriptif analitis.
\end{abstract}

\section{Kata Kunci: Perkawinan, Sejenis, Eksistensialisme, Hak, Asasi}

\section{Abstract}

A marriage is generally legalized in some countries for couples consisting of one male and one female. But similar marriage is a different matter. This type of marriage is often done between men and women and women. This marriage is considered as the right of the individual to shape his own life, so that anyone cannot forbid it, so does the existentialism flow which states that every individual is given the greatest freedom. Of course, this freedom makes an individual do things he thinks are right because it is from his own right as an individual. In HAM also states that the right to freedom of association contains elements of the right to freedom and social rights and freedom of religion shows the distinctive personal and collective rights, but if we examine it more deeply it is clear that freedom in question is freedom that has boundaries that must be met as well; does it violate decency, religion, or the integrity of the nation? The purpose of this study is to find out same-sex marriage in the existentialism flow and to know the human rights perspective in criticizing same-sex marriage. This study uses a normative juridical approach and the nature of this research is descriptive analytical.

Keywords: Similar, Marriage, Existentialism, Human, Rights 
DE LEGA LATA

Jurnal Ilmu Hukum

FAKULTAS HUKUM UMSU
Perkawinan Sejenis Dalam...(Otong Syuhada)

Volume 4 Nomor 1, Januari-Juni 2019, 87-102 DOI: https://doi.org/10.30596/dll.v4i1.3168

\section{PENDAHULUAN}

Perkawinan merupakan salah satu hal penting dalam kehidupan manusia, dan melalui lembaga perkawinan jumlah manusia di muka bumi akan semakin bertambah, karena keturunan manusia tidak akan berlanjut tanpa adanya perkawinan. Perkawinan menyebabkan adanya keturunan dan melalui keturunan tentunya tercipta keluarga yang berkembang menjadi masyarakat, sedangkan masyarakat dapat diartikan sebagai bentuk kehidupan bersama yang di dalam nya terdapat individu dan/atau kelompok sebagai anggotanya yang saling mengadakan interaksi untuk kelangsungan hidupnya (Tengku Erwinsyahbana, 2012, h. 1).

Sebuah perkawinan umumnya dibeberapa Negara dilegalkan untuk pasangan yang terdiri dari satu laki-laki dan satu perempuan. Namun perkawinan sejenis merupakan hal yang berbeda. Perkawinan sejenis ini kerap dilakukan antara pria dengan pria maupun wanita dengan wanita. Perkawinan ini dianggap sebagai hak dari individu untuk membentuk hidupnya sendiri, sehingga siapapun tidak dapat melarangnya. Hal tersebut didasari atas aliran Eksistensialisme yang menekankan pada manusia yang bertanggung jawab atas kemauannya yang bebas tanpa memikirkan secara mendalam mana yang benar dan mana yang tidak benar. Dari pandangan inilah maka lahir pemikiran-pemikiran mengenai Perkawinan sesama jenis.

Namun di Indonesia belum terdapat pengaturan yang menjelaskan mengenai Perkawinan sejenis, hanya dalam Undang-Undang Nomor 1 tahun 1974 mengenai perkawinan, menyatakan bahwa perkawinan ialah ikatan lahir bathin antara seorang pria dengan seorang wanita. Berkaitan dengan paparan di atas, filsafat merupakan ilmu yang berupaya untuk memahami hakikat realitas yang ada dengan mengandalkan akal budi (Jan Hendrik Rapar, 2010, h. 15). Karena filsafat mencoba memahami segala realitas yang ada, sehingga objeknya melingkupi segala yang ada termasuk juga manusia.

Ketika filsafat berobjekkan manusia, filsafat menjadi ilmu yang mengaji tentang selukbeluk manusia. Dalam artian, filsafat akan membahas mengenai manusia secara mendalam, baik dari unsur dan fungsi hidupnya. Dalam Kamus Besar Bahasa Indonesia, manusia disebutkan sebagai alam kecil yang merupakan bagian dari alam besar yang ada di atas alam. Ia adalah makhluk yang bernyawa, makhluk antromorphen dan merupakan binatang yang menyusui, akan tetapi juga merupakan makhluk yang dapat mengetahui dan menguasai kekuatan-kekuatan alam di luar dan di dalam dirinya, baik lahir maupun batin. ( Departemen Pendidikan dan Kebudayaan, 1987, h. 291).

Al-Qur'ean menyebutkan manusia dengan beberapa istilah, yaitu basyar, insân dan nâs. Istilah basyar mempunyai arti bahwa manusia merupakan makhluk yang terdiri dari karakteristik fisiologis, biologis dan psikologis (Charles Kurzman, 2003, h. 300.). Istilah insân digunakan dalam Al-Qur'an untuk menunjuk kepada manusia dengan seluruh totalitasnya, yaitu jiwa dan raga dan Allah menciptakan manusia dari tanah kemudian dari air mani, kemudian Allah menjadikan manusia berpasangan (laki-laki dan perempuan). Namun semenjak keberadaan manusia hingga sampai saat ini masalah kesusilaan sering menjadi topik penting dan menarik untuk didiskusikan. 
Jurnal Ilmu Hukum

FAKULTAS HUKUM UMSU
Perkawinan Sejenis Dalam...(Otong Syuhada)

Volume 4 Nomor 1, Januari-Juni 2019, 87-102 DOI: https://doi.org/10.30596/dll.v4i1.3168

Kesusilaan sangat terkait erat dengan hakikat manusia sebagai mahluk ciptaan Tuhan yang bermoral. Nilai kesusilaan sebagai hasil dari penghayatan manusia atas keberadaan diri dan relasinya dengan masyarakat menciptakan sebuah tatanan hidup masyarakat yang berbeda antara yang satu dengan lainnya (Hwian Christianto, 2015, h. 61).Dengan demikian sejak dahulu nilai moral merupakan hal yang paling esensial dalam menata kesedapan hidup bersama di masyarakat.

Lahirnya filsafat (B. Arief Sidharta, 2008, h. 23) di abad ke-enam tidak terlepas dari pemikiran bahwa manusia (hominis) itu bukanlah dewa-dewa (deus) dan bukanlah juga binatang/ serigala (lupus), ia berada diantara (in between) kedua mahluk tersebut, karena berada diantara keduanya kadang sering terjadi tarik menarik posisinya, akibatnya konon ada hominis yang saking bijaksananya menjaga kehidupannya dalamkesucian ia diumpamakan bagaikan deus (dewa/malaikat), dan sebaliknya ada juga hominis yang saking mengikuti sifat evil things di dalam dirinya sehingga menjadi terdegradasi kelakuan dan tindak-tanduknya bagaikan lupus hingga melahirkan adagium 'manusia menjadi serigala buat manusia yang lain' (homo homini lupus).

Dengan konteks realitas manusia bukanlah deus dan bukan jugalah lupus maka Plato dalam karyanya Phaidros, menerangkan bahwa;

Kata 'makhluk bijak' (Sophos) terlalu luhur untuk seorang manusia. Kata itu pantas untuk Dewa. Bagi Plato lebih baik manusia dijuluki sebagai pencinta kebijakan atau philosphos. Sejak saat itulah philosophos berkembang sebagai sebuah sebutan bagi manusia yang mencari dan mencintai kebijaksanaan" (Antonius Cahyadi, dan E. Fernando M. Manullang, 2008, h. 5).

Di dalam proses mencintai kebijakan inilah, maka manusia akan memahami apa itu manusia (ontologi), dari mana ia datang (epistemologi) dan hendak kemanakah ia pergi atau apa fungsi dan manfaat manusia ada (aksiologi). Itulah sebabnya dalam berfilsafat ontologi dan epistemologi, harus diakhiri dengan aksiologi, karena dengan demikian manusia akan memahami maknanya sebagai manusia. Oleh karena filsafat juga membicarakan "manfaat" (aksiologi) sebagai salah satu sub penyelidikannya, maka pada akhirnya keinginan dan harapan kelompok LGBT agar perkawinan sesama jenis (same sex marriage) dapat dilegalisasi setara di dalam hukum perkawinan Indonesia sebagaimana sudah terjadi di berbagai negara Eropa dan Amerika Serikat, harus digali secara radikal aksiologinya yaitu seberapa 'bermanfaatkah' kedalaman realitasnya perkawinan sesama jenis bermanfaat untuk kemaslahatan humana dan humanisme.

Mengkaji perkawinan sejenis yang dianggap menyimpang ini, sebelumnya perlu dipahami terlebih dahulu apa yang dimaksud dengan perilaku menyimpang itu sendiri. Tingkah laku abnormal atau menyimpang adalah tingkah laku yang tidak adekutat, tidak bisa diterima oleh masyarakat pada umumnya, dan tidak sesuai dengan norma sosial yang ada (Kartini Kartono, 2007:14). Seorang individu atau kelompok yang dalam mencapai tujuannya tidak dapat menyesuaikan dengan norma yang berlaku maka disebut deviasi. Deviasi adalah penyimpangan terhadap kaidah dan nilai-nilai masyarakat (Soerdjono Soekanto, 2007, h. 
DE IEGA LATA

Jurnal Ilmu Hukum

FAKULTAS HUKUM UMSU
Perkawinan Sejenis Dalam...(Otong Syuhada)

Volume 4 Nomor 1, Januari-Juni 2019, 87-102 DOI: https://doi.org/10.30596/dll.v4i1.3168

189). Fenomena penyuka sejenis di Indonesia merupakan suatu fenomena yang dianggap suatu perilaku menyimpang dari norma-norma yang berlaku di masyarakat namun perilaku ini masih saja ada dan terjadi. Dalam pandangan kita, kehidupan yang ideal (dalam konteks seksual) adalah pasangan yang berbeda jenis atau antara laki-laki dan perempuan akan tetapi di samping itu ada kecenderungan untuk pasangan yang bukan berbeda jenis seperti halnya homoseksual ini (laki-laki dan laki-laki). Tentunya fenomena ini masih sulit diterima oleh masyarakat akan tetapi dikehidupan lain itu memang benar-benar ada.

Saat ini kaum penyuka sesama jenis tidak lagi malu untuk menunjukkanidentitasnya dan bahkan mereka tidak ragu lagi untuk menggalang massa agarvkomunitas diantara mereka semakin banyak dan dapat diterima di masyarakat luas. Contohnya, saat ini para netizen penikmat media sosial dihebohkan dengan adanya account Instagram yang menamai dirinya adalah gay_bandung, dimana di dalam account Instagram tersebut berisikan foto-foto lelaki yang sedang melakukan hubungan "intim" sesama jenis dan di Instagram tersebut langsung terkoneksi dengan aplikasi Line, sehingga para followers bisa berkomunikasi langsung dengan pemilik account tersebut.

Selain Instagram, banyak website yang kini sangat terang-teranganmemfasilitasi para penyuka sesama jenis untuk menemukan komunitasnya seperti www.jakartagaypersonal.com dan www.gayxchange.com. Hal ini adalah contoh nyata dimana kaum penyuka sesama jenis semakin hari semakin merdeka mengembangkan sayapnya di kehidupan bermasyarakat. Bahkan, banyak berita yang menyebutkan bahwa kaum tersebut mengincar anak-anak dibawah umur sebagai korban.

Legalitas Perkawinan sesama jenis adalah kewajiban hukum dalam melindungi setiap individu tanpa membedakan gendernya, pada dasarnya homoseksualitas maupun lesbian dimata hukum semuanya sama, mereka mendapat kebebasan memeluk agama, berpendapat, memiliki hak untuk hidup dan mendapat perlindungan hukum, dan sebagainya. Demikianlah legalitas Perkawinan sesama jenis jika mereka tidak merugikan ataupun menggangu mereka yang normal, dan kita yang normal bukan membuat mereka menderita dan merasa tidak diakui karena tindakan penyimpangan itu. Karena Homoseksual adalah suatu penyakit maka kita harus melakukan upaya untuk penyembuhan terhadap perilaku itu bukan pada penolakan terhadap penyakitnya tetapi pada tindakannya lah yang harus dibenahi dan diarahkan pada hal yang sewajarnya. Maka pentingnya kita untuk memahami Hak asasi manusia sebagai nilainila moral yang universal paling luhur (Ahmad Ramali, 2012, h. 73).

Pakar HAM seperti Van Boven dalam tulisannya yang menyatakan bahwa hak untuk bebas berserikat mengandung unsur hak kebebasan maupun hak sosial dan kebebasan beragama menunjukkan ciri khas hak pribadi maupun kolektif (Theo C. Van Boven, 1982, h. 59). Selain itu, Peter R. Baehr dalam bukunya yang berjudul mengatakan bahwa Hak Asasi Manusia (HAM) ialah hak dasar yang bersifat mutlak dan juga harus dipunyai pada tiap insan untuk perkembangan dirinya tersebut(Peter R. Baehr, 2001, h. 178). Tetapi jika kita telaah lebih dalam sudah jelas dikatakan bahwa kebebasan yang dimaksud adalah kebebasan yang memiliki batasan-batasan yang harus dipenuhi pula seperti; apakah melanggar kesusilaan, 
DE LEGA LATA

Jurnal Ilmu Hukum

FAKULTAS HUKUM UMSU
Perkawinan Sejenis Dalam...(Otong Syuhada)

Volume 4 Nomor 1, Januari-Juni 2019, 87-102 DOI: https://doi.org/10.30596/dll.v4i1.3168

agama, maupun keutuhan bangsa?

Mengenai hal itu, Indonesia telah mengaturnya dalam Undang-Undang Republik Indonesia Nomor 39 Tahun 2009 tentang HAM dalam Pasal 30 yang menyatakan: "Setiap orang berhak atas rasa aman dan tenteram serta perlindungan terhadap ancaman ketakutan untuk berbuat atau tidak berbuat sesuatu" dan Pasal 35 bahwa "Setiap orang berhak hidup di dalam tatanan masyarakat dan kenegaraan yang damai, aman, dan tenteram yang menghormati, melindungi, dan melaksanakan sepenuhnya hak asasi manusia dan kewajiban dasar manusia sebagaimana diatur dalam undang-undang ini". Di dalam agama Islam, dimana agama Islam menjadi agama mayoritas di Indonesia, Allah SWT melarang keras hamba-Nya agar tidak masuk ke dalam golongan orang-orang yang menyukai sesama jenis, seperti lesbi ataupun gay, biseksual, dan transgender.

Perkawinan sejenis ini juga tidak lepas kaitannya dari aliran eksistensialisme dikarenakan dalam aliran ini setiap individu diberikan kebebasan sebesar-besarnya. Tentu saja kebebasan tersebut membuat individu melakukan hal-hal yang dianggapnya benar karena merupakan dari haknya sendiri sebagai seorang individu. Begitu halnya juga dengan perkawinan sejenis yang dilakukan oleh pria dengan pria maupun wanita dengan wanita, mereka menganggap Perkawinan adalah hak dari individu, dan mereka bebas untuk menentukan jalan hidup mereka sendiri seperti yang diinginkan, sehingga tidak salah jika mereka berkehendak untuk menikah dengan sesamanya.

Melihat aliran Eksistensialisme yang menjungjung tinggi kebebasan dan hak-hak individu maka Perkawinan sesama jenis tidak merupakan sebuah pelanggaran. Perkawinan sesama jenis merupakan hak dan kebebasan dari individu tersebut tidak ada yang dapat menghalangi ataupun mengurangi hak individu tersebut selama kebebasan dari individu tersebut tidak mengganggu kebebasan dari individu lain, sehingga baik itu pemerintah melalui peraturan perundang-undangan ataupun agama melalui aturan-aturannya tidak dapat melarangnya.

\section{METODE PENELITIAN}

Spesifikasi Penelitian termasuk jenis penelitian deskriptif-analitis. Menurut Soejono Soekanto, yaitu:

Penelitian yang bersifat deskriptif-analitis, dimaksudkan untuk memberikan data yang seteliti mungkintentang manusia, keadaan, atau gejala-gejala tertentu.Maksudnya adalah untuk mempertegas hipotesa, agar dapatmemperluas teori-teori lama atau didalam kerangkamenyusun teori-teori baru (Soejono Soekanto, 1986, h. 119).

Sifat penulisan yang digunakan adalah deskriptif analistis, yaitu menggambarkan permasalahan yang diteliti berupa fakta-fakta dan permasalahan seputar perkawinan sejenis dengan teori-teori hukum dan aliran eksistensialisme dikaitkan dengan Hak Asasi Manusia. Jenis penelitian ini adalah yuridis normatif, karena kajian dalam penelitian ini adalah kajian ilmu hukum, oleh karena itu harus dikaji dari aspek hukumnya. Penelitian yuridis normatif disebut juga penelitian hukum kepustakaan (Ronny Hanitijo Soemitro, 1988, h. 11), atau 
Jurnal Ilmu Hukum

FAKULTAS HUKUM UMSU
Perkawinan Sejenis Dalam...(Otong Syuhada)

Volume 4 Nomor 1, Januari-Juni 2019, 87-102 DOI: https://doi.org/10.30596/dll.v4i1.3168

dikategorikan sebagai penelitian yang mengkaji asas-asas dan kaidah-kaidah hukum (Ronny Hanitijo Soemitro, 1990, h. 11-12). Digunakannya penelitian hukum normatif, karena permasalahan pokoknya mengenai perkawinan sejenis dikaitkan dengan aliran eksistensialisme dan Hak Asasi Manusia, dan pendekatannya menggunakan pendekatan perundang-undangan (statute approach) yaitu dilakukan dengan menelaah semua undangundang dan regulasi yang berkaitan dengan perkawinan sejenis.

Di dalam memperoleh data yang relevan dengan permasalahan yang diteliti, maka penelitian ini dilaksanakan dalam 2 (dua) tahap, yaitu: pertama, penelitian kepustakaan dan kedua, studi lapangan. Penelitian kepustakaan dilakukan dalam rangka memperoleh data sekunder, baik yang berupa bahan hukum primer, bahan hukum sekunder, maupun bahan hukum tertier (Soerjono Soekanto dan Sri Mamudji, 2003, h. 13). Bahan hukum primer adalah bahan hukum yang bersifat autoritatif (mempunyai otoritas), dan bahan-bahan hukum yang mengikat, yakni norma (dasar) atau kaidah dasar dan peraturan-peraturan dasar, seperti Undang-Undang Dasar 1945, serta peraturan perundang-undangan yang berkaitan dengan perkawinan sejenis.

Bahan hukum sekunder adalah bahan hukum yang memberikan penjelasan mengenai bahan hukum primer, berupa hasil-hasil penelitian, karangan ilmiah dari kalangan hukum, dan penelitian-penelitian lain yang relevan dengan penelitian ini, sedangkan bahan hukum tertier adalah bahan yang memberikan petunjuk ataupun penjelasan terhadap bahan hukum primer dan bahan hukum sekunder, berupa kamus, ensiklopedia, majalah, surat kabar dan sebagainya yang dipergunakan untuk melengkapi ataupun menunjang data penelitian ini. Selanjutnya studi lapangan dilakukan dalam rangka memperoleh data primer yang menunjang data sekunder, sehingga dari data primer akan diketahui pelaksanaan penanggulangan perkawinan sejenis.

Teknik pengambilan data yang dilakukan adalah dengan menggunakan teknik:

1. Teknik pengambilan data dalam penelitian kepustakaan berupa catatan-catatan hasil inventarisasi bahan hukum primer, sekunder, dan tersier. Bahan hukum tersebut juga dapat berupa dokumentasi, yaitu pengambilan data-data dengan melakukan review terhadap dokumen yang berkaitan dengan masalah tersebut.

2. Teknik pengambilan data dalam penelitian lapangan yang berupa interview, yaitu pengambilan data yang dilakukan dengan mengadakan tatap muka atau wawancara pada anggota komunitas lesbi, gay, biseksual, dan transgender (LGBT) maupun pada warga masyarakat setempat untuk menganalisis mengenai penyebab seseorang melakukan perkawinan sejenis.

Setelah data sekunder dan primer terkumpul, kemudian diadakan analisis secara yuridis kualitatif, yaitu menganalisis data berupa uraian-uraian yang sistematis tanpa mempergunakan bagan-bagan dan rumus statistik.

\section{PEMBAHASAN}

\section{Perkawinan Sesama Jenis Dalamaliran Eksistensialisme}


DE LEGA LATA

Jurnal Ilmu Hukum

FAKULTAS HUKUM UMSU
Perkawinan Sejenis Dalam...(Otong Syuhada)

Volume 4 Nomor 1, Januari-Juni 2019, 87-102 DOI: https://doi.org/10.30596/dll.v4i1.3168

Filsafat eksistensialisme adalah salah satu aliran filsafat yang mengguncang-kan dunia walaupun filsafat ini tidak luar biasa dan akar-akarnya ternyata tidak dapat bertahan dari berbagai kritik (Tafsir, Ahmad. 1992, h. 190). Filsafat selalu lahir dari suatu krisis. Krisis berarti penentuan. Bila terjadi krisis, orang biasanya meninjau kembali pokok pangkal yang lama dan mencoba apakah ia dapat tahan uji (R.F. Beerling, 1966, h. 11). Dengan demikian filsafat adalah perjalanan dari satu krisis ke krisis yang lain. Begitu juga filsafat eksistensialisme lahir dari berbagai krisis atau merupakan reaksi atas aliran filsafat yang telah ada sebelumnya atau situasi dan kondisi dunia, yaitu:

\section{Materialisme}

Menurut pandangan materialisme, manusia itu pada akhirnya adalah benda seperti halnya kayu dan batu. Memang orang materialis tidak mengatakan bahwa manusia sama dengan benda, akan tetapi mereka mengatakan bahwa pada akhirnya, jadi pada prinsipnya, pada dasarnya, pada instansi yang terakhir manusia hanyalah sesuatu yang material; dengan kata lain materi; betul-betul materi. Menurut bentuknya memang manusia lebih unggul ketimbang sapi tapi pada eksistensinya manusia sama saja dengan sapi (Tafsir, Ahmad. 1992, h. 192).

\section{Idealisme}

Aliran ini memandang manusia hanya sebagai subyek, hanya sebagai kesadaran; menempatkan aspek berpikir dan kesadaran secara berlebihan sehingga menjadi seluruh manusia, bahkan dilebih-lebihkan lagi sampai menjadi tidak ada barang lain selain pikiran. (Tafsir, Ahmad. 1992, h. 193).

\section{Situasi dan Kondisi Dunia}

Munculnya eksistensialisme didorong juga oleh situasi dan kondisi di dunia Eropa Barat yang secara umum dapat dikatakan bahwa pada waktu itu keadaan dunia tidak menentu. Tingkah laku manusia telah menimbulkan rasa muak atau mual. Penampilan manusia penuh rahasia, penuh imitasi yang merupakan hasil persetujuan bersama yang palsu yang disebut konvensi atau tradisi. Manusia berpura-pura, kebencian merajalela, nilai sedang mengalami krisis, bahkan manusianya sendiri sedang mengalami krisis. Sementara itu agama di sana dan di tempat lain dianggap tidak mampu memberikan makna pada kehidupan. (Tafsir, Ahmad. 1992, h. 194).

Soren Aabye Kierkegaard salah satu tokoh eksistensialisme menyatakan bahwa bagi manusia, yang terpenting dan utama adalah keadaan dirinya atau eksistensi dirinya. Eksistensi manusia bukanlah statis tetapi senantiasa menjadi, artinya manusia itu selalu bergerak dari kemungkinan kenyataan. Proses ini berubah, bila kini sebagai sesuatu yang mungkin, maka besok akan berubah menjadi kenyataan. Karena manusia itu memiliki kebebasan, maka gerak perkembangan ini semuanya berdasarkan pada manusia itu sendiri. Eksistensi manusia justru terjadi dalam kebebassannya. Kebebasan itu muncul dalam aneka perbuatan manusia. Baginya bereksistensi berarti berani mengambil keputusan yang menentukan bagi hidupnya. Konsekuensinya, jika kita tidak berani mengambil keputusan dan tidak berani berbuat, maka kita tidak bereksistensi dalam arti sebenarnya.(Dagun, 1990, h. 51)

Kierkegaard membedakan tiga bentuk eksistensi, yaitu estetis, etis, dan religius dengan 
Jurnal Ilmu Hukum

FAKULTAS HUKUM UMSU
Perkawinan Sejenis Dalam...(Otong Syuhada)

Volume 4 Nomor 1, Januari-Juni 2019, 87-102 DOI: https://doi.org/10.30596/dll.v4i1.3168

uraian sebagai berikut; (Harun Hadiwijono,1980, h. 125)

a. Eksistensi estetis menyangkut kesenian, keindahan. Manusia hidup dalam lingkungan dan masyarakat, karena itu fasilitas yang dimiliki dunia dapat dinikmati manusia sepuasnya. Di sini eksistensi estetis hanya bergelut terhadap hal-hal yang dapat mendatangkan kenikmatan pengalaman emosi dan nafsu. Eksistensi ini tidak mengenal ukuran norma, tidak adanya keyakinan akan iman yang menentukan.

b. Eksistensi etis. Setelah manusia menikmati fasilitas dunia, maka ia juga memperhatikan dunia batinnya. Untuk keseimbangan hidup, manusia tidak hanya condong pada hal-hal yang konkrit saja tapi harus memperhatikan situasi batinnya yang sesuai dengan norma-norma umum. Sebagai contoh untuk menyalurkan dorongan seksual (estetis) dilakukan melalui jalur perkawinan (etis).

c. Eksistensi religius. Bentuk ini tidak lagi membicarakan hal-hal konkrit, tetapi sudah menembus inti yang paling dalam dari manusia. Ia bergerak kepada yang absolut, yaitu Tuhan. Semua yang menyangkut Tuhan tidak masuk akal manusia. Perpindahan pemikiran logis manusia ke bentuk religius hanya dapat dijembatani lewat iman religius.

Menurut Kierkegaard, antara Tuhan dengan alam, antara pencipta dan makhluk terdapat jurang yang tidak terjembatani. Ia menjelaskan bahwa Tuhan itu berdiri di atas segala ukuran sosial dan etika. Sedangkan manusia jauh berada di bawah-Nya. Keadaan seperti ini menyebabkan manusia cemas akan eksistensinya. Tetapi dalam kecemasan ini, seseorang itu dapat menghayati makna hidupnya. Jika seseorang itu berada dalam kecemasan, maka akan membawa dirinya pada suatu keyakinan tertentu. Perilaku ini memperlihatkan suatu loncatan yang dahsyat di mana manusia memeluk hal yang tidak lagi masuk akal (Dagun, 1990, h. 52).

Para filsuf eksistensialis adalah mereka yang paling gagah berada pada garda depan ketika membicarakan hak dan kebebasan universal manusia. Sebut saja misalnya Jean-Paul Sartre, ada diktum Satre yang sangat terkenal, human is condemned to be free (manusia dikutuk untuk bebas).Kebebasan menjadi semacam kutukan yang melekat pada diri manusia. Karena ada pengandaian ruang eksistensial yang tak terbatas dalam dunia. Keterlemparan manusia pada dunia, yang oleh Martin Heidegger disebut sebagai faktisitas, diharapkan dapat seutuhnya menghadirkan manusia merdeka dengan ruang eksistensialnya.

Hanya ada yang tak boleh dilupa, seberapapun kebebasan didengungkan oleh para eksistensialis atas nama hak kemanusiaan, mereka tetap secara utuh menyadari bahwa ketika kebebasan merupakan satu-satunya universalitas manusia, maka kebebasan dari individu yang lain adalah batasan terhadap kebebasannya. Itu artinya, para eksistensialis ingin hadir seutuhnya ke dalam dunia, tak hanya atas nama dirinya namun juga orang lain. Karakter monodualis manusia sebagai makhluk individual dan sosial, tak akan terelakkan dalam kehidupan kita.

Pada kondisi ini, kita dapat melihat kenyataan tentang LGBT di Indonesia dalam sudut pandang keterkaitan eksistensialis dalam perkawinan sejenis sebagai basis humanisme universal. Kita selalu mengandaikan kebebasan dapat hadir dalam diri, hanya kadang kealpaan kita terlampau besar terhadap hak-hak kebebasan orang lain. Saya sebagai pribadi 
DE LEGA LATA

Jurnal Ilmu Hukum

FAKULTAS HUKUM UMSU
Perkawinan Sejenis Dalam...(Otong Syuhada)

Volume 4 Nomor 1, Januari-Juni 2019, 87-102 DOI: https://doi.org/10.30596/dll.v4i1.3168

sesungguhnya tak ada masalah dengan pelaku LGBT, itu hak personal setiap orang. Hanya ketika LGBT hadir dalam ruang komunal kita, persoalan yang bakal muncul kemudian adalah rusaknya sistem kehidupan sosial kita berkaitan dengan reproduksi dan regenerasi kemanusiaan di masa depan (Masduri, 2018 ).

Hubungan antar lawan jenis dalam agama-agama sangat diatur secara ketat, karena berkaitan dengan reproduksi dan regenerasi kemanusiaan. Maka aturan perkawinan merupakan jalan sakral yang memiliki dimensi transendental, sebagai pembenar terhadap perilaku seksual dalam kehidupan manusia. Karena itu, ketika hadir LGBT, sesungguhnya kita dihadapkan pada paradoks masa depan kemanusiaan kita. Tak terbayang, bagaimana ketika perilaku menyimpang LGBT direproduksi sedemikian rupa dalam pentas sosial kita. Kemudian hal itu menjadi perilaku sosial yang berpengaruh secara masif terhadap kecenderungan perilaku seksual masyarakat. Bukan tak mungkin masa depan regenerasi kemanusiaan kita semakin kelabu hingga titik nadir.

Penolakan mayoritas masyarakat terhadap pelaku LGBT harus dapat ditempatkan dalam kerangka pemanusiaan manusia. Bukan sebaliknya dinilai sebagai perangkap dan pengekangan hak kemanusiaan. Kalau kita hendak berpikir jernih, perilaku menyukai dan melakukan hubungan seks pada sesama jenis, sesungguhnya mengingkari kodrat transendental kemanusiaan kita, sebagai makhluk yang diciptakan berpasang-pasangan antara lakilaki dan perempuan. Perbedaan alat kelamin merupakan kenyataan seksual guna menghadirkan reproduksi dan regenerasi keturunan manusia. Kalau perilaku menyukai sesama jenis dibiarkan, ancamannya adalah masa depan kemanusiaan kita bersama di bumi (Masduri, 2018).

Perkawinan sejenis jika dikaitkan dengan Hukum progresif yang menyatakan bahwa hukum untuk manusia, bukan manusia untuk hukum. Manusia yang mana tentunya manusia Indonesia yang berlandaskan Pancasila. Perkawinan sejenis jelas dilarang dilakukan di Negara Indonesia. Hal ini dikarenakan bertentangan dengan nilai-nilai Pancasila terutama sila ke satu/pertama dari Pancasila yaitu ke-Tuhanan Yang Maha Esa. Di dalam sila pertama ini mengatur tentang kehidupan berkeagamaan yang didalam nya terdapat 6 agama yang di akui di Negara Repubulik Indonesia ini dan semuanya sepakat tidak menghendaki adanya perkawinan sejenis.

Hukum progresif bermakna hukum yang peduli terhadap kemanusiaan sehingga bukan sebatas dogmatis belaka. Secara spesifik hukum progresif antara lain bisa disebut sebagai hukum yang pro rakyat dan hukum yang berkeadilan. Konsep hukum progresif adalah hukum tidak ada untuk kepentingannya sendiri, melainkan untuk suatu tujuan yang berada di luar dirinya. Oleh karena itu, hukum progresif meninggalkan tradisi analytical jurisprudence atau rechtsdogmatiek.

Aliran-aliran tersebut hanya melihat ke dalam hukum dan membicarakan serta melakukan analisis ke dalam, khususnya hukum sebagai suatu bangunan peraturan yang dinilai sebagai sistematis dan logis. Hukum progresif bersifat responsif yang mana dalam responsif ini hukum akan selalu dikaitkan pada tujuan-tujuan di luar narasi tekstual hukum itu 
Jurnal Ilmu Hukum

FAKULTAS HUKUM UMSU
Perkawinan Sejenis Dalam...(Otong Syuhada)

Volume 4 Nomor 1, Januari-Juni 2019, 87-102 DOI: https://doi.org/10.30596/dll.v4i1.3168

sendiri .

Kehadiran hukum dikaitkan pada tujuan sosialnya, maka hukum progresif juga dekat dengan sociological jurisprudence dari Roscoe Pound. Hukum progresif juga mengundang kritik terhadap sistem hukum yang liberal, karena hukum Indonesia pun turut mewarisi sistem tersebut. Satu moment perubahan yang monumental terjadi pada saat hukum pra modern menjadi modern. Disebut demikian karena hukum modern bergeser dari tempatnya sebagai institusi pencari keadilan menjadi institusi publik yang birokratis. Hukum yang mengikuti kehadiran hukum modern harus menjalani suatu perombakan total untuk disusun kembali menjadi institusi yang rasional dan birokratis. Akibatnya hanya peraturan yang dibuat oleh legislatiflah yang sah yang disebut sebagai hukum.

Progresifisme hukum mengajarkan bahwa hukum bukan raja, tetapi alat untuk menjabarkan dasar kemanusiaan yang berfungsi memberikan rahmat kepada dunia dan manusia. Asumsi yang mendasari progresifisme hukum adalah pertama hukum ada untuk manusia dan tidak untuk dirinya sendiri, kedua hukum selalu berada pada status law in the making dan tidak bersifat final, ketiga hukum adalah institusi yang bermoral kemanusiaan. Oleh karena itu perkawinan sejenis merupakan suatu tindakan penyimpangan prilaku dan bertentangan dengan moral yang hidup di negeri ini.Berdasarkan asumsi-asumsi di atas maka kriteria hukum progresif adalah:

a. Mempunyai tujuan besar berupa kesejahteraan dan kebahagiaan manusia.

b. Memuat kandungan moral kemanusiaan yang sangat kuat.

c. Hukum progresif adalah hukum yang membebaskan meliputi dimensi yang amat luas yang tidak hanya bergerak pada ranah praktik melainkan juga teori.

d. Bersifat kritis dan fungsional.

Perkawinan Sesama Jenis jika dikaitkan dengan Aliran Eksistensialisme ada diktum Satre yang sangat terkenal, human is condemned to be free (manusia dikutuk untuk bebas).Kebebasan menjadi semacam kutukan yang melekat pada diri manusia. Karena ada pengandaian ruang eksistensial yang tak terbatas dalam dunia makasetiap individu yang akan melakukan perkawinan termasuk perkawinan sejenis diberikan kebebasan sebesar-besarnya dan tentu saja kebebasan tersebut membuat individu melakukan hal-hal yang dianggapnya benar karena merupakan dari haknya sendiri sebagai seorang individu. Begitu halnya juga dengan perkawinan sejenis yang dilakukan oleh pria dengan pria maupun wanita dengan wanita, mereka menganggap perkawinan adalah hak dari individu, dan mereka bebas untuk menentukan jalan hidup mereka sendiri seperti yang diinginkan. Namun perkawinan sejenis itu bila ditinjau dari teori hukum progresif dan tujuan hukum secara sosiologi perbuatan perkawinan sejenis bertentangan dengan nilai-nilai yang hidup ditengah-tengah masyarakat, misalnya adat istiadat dan 6 (enam ) agama yang dianut di Negara kita.

\section{Perspektif HAM Dalam Mengkritisi Perkawinan Sesama Jenis.}

Isu pelegalan perkawinan sesama jenis seringkali berkedok atas nama HAM (Hak Asasi Manusia). Mereka berdalih bahwa manusia berhak untuk menentukan kehidupannya sendiri. 
Jurnal Ilmu Hukum

FAKULTAS HUKUM UMSU
Perkawinan Sejenis Dalam...(Otong Syuhada)

Volume 4 Nomor 1, Januari-Juni 2019, 87-102 DOI: https://doi.org/10.30596/dll.v4i1.3168

dalam kaitan tentang perkawinan, manusia berhak menentukan dengan siapa ia akan melangsungkan perkawinan baik dengan lawan jenis maupun sesama jenis kelaminnya.

Para kaum LGBT (Lesbi-Gay Biseksual dan Transgender) mengklaim bahwa kelompok mereka sering mendapatkan perilaku diskriminasi dari masyarakat tentang perilaku menyimpangnya. Dengan dasar ini mereka sering meminta perlindungan atas nama HAM. Tak segan mereka juga mendatangi Komnas HAM untuk mengajukan beberapa tuntutan agar eksistensi dan status mereka diakui oleh masyarakat. Meskipun usulan mereka belum mengarah pada legalisasi perkawinan sesama jenis tetapi jika terus-terusan diakomodir bukan tidak mungkin suatu saat Undang-Undang Nomor 1 Tahun 1974 tentang Perkawinan di Indonesia dan bukan tidak mungkin juga nantinya perkawinan sesama jenis di Indonesia menjadi legal.Prinsip-prinsip dalam HAM memang sangat universal atau menekankan kebebasan secara umum. Namun dalam implementasi, HAM sama sekali tidak menghilangkan unsur realitas lokal.

HAM tidak merupakan persamaan kata dengan pelampiasan kepuasan. Penafsiran secara substansial tentang HAM bukan mutlak datang dari pemahaman aliran liberalultitarian-hedonis. Hak Asasi Manusia memang menjamin kemerdekaan dan kebebasan tiap individu, namun yang perlu diingat adalah kebebasan tersebut bukan kebebasan yang tanpa batas. Patokan penegakan HAM di Indonesia yang merupakan hasil dari Declaration of Human Right tentunya sudah diratifikasi terlebih dahulu dan disesuaikan agar tidak bertentangan dengan Undang-Undang Dasar 1945 (Khairudin Aji Laksono, 2018).

Pasal-pasal dalam Deklarasi Universal Hak Asasi Manusia (DUHAM) itu ada yang ketat, ada pula yang longgar. Contohnya, Pasal 16 DUHAM tentang hak untuk menikah dan berkeluarga. Dalam pasal itu, tidak ada indikasi dibolehkannya perkawinan sejenis. Sehingga dibutuhkan penjelasan lebih lanjut dalam konvensi dan hukum nasional. DUHAM PBB dalam pelaksanaannya bergantung pada hukum nasional suatu negara (walaupun sudah meratifikasi DUHAM PBB) karena hukum yang paling mengikat adalah hukum nasional. Oleh karena itu negara seperti Indonesia tidak secara otomatis seluruhnya mengikuti isi setiap pasal dari DUHAM PBB, walaupun Indonesia telah meratifikasi DUHAM PBB. Semua isi pasal harus disesuaikan dengan hukum nasional dan kondisi Indonesia (Maneger Nasution, 2018).

Indonesia adalah salah satu negara yang tidak membolehkannya berlakunya perkawinan sejenis. Di negara lain, ada yang membolehkan, seperti Belanda dan Amerika. Jadi, DUHAM PBB merupakan perangkat hukum internasional yang bertindak sebagai payung dalam bidang HAM. Namun Indonesia tidak dapat memberlakukan perkawinan sesama jenis ke dalam bentuk regulasi. Sebab, Perkawinan sesama jenis bertentangan dengan ideologi negara, Pancasila, dan konstitusi Indonesia. Konstitusi Indonesia menganut asas Ketuhanan Yang Maha Esa sebagai core Pancasila yang menunjukkan bila bangsa Indonesia merupakan bangsa beragama. Sebagai bangsa beragama, sudah sejatinya menolak Perkawinan sesama jenis karena perilaku menyimpang. Di samping DUHAM PBB, landasan filosofis HAM-nya adalah sila kedua Pancasila, Kemanusiaan yang Adil dan Beradab. Sebagai bangsa beradab, tentu Indonesia menolak penyimpangan seksual komunitas lesbian, gay, biseksual, transgender 
DE LEGA LATA

Jurnal Ilmu Hukum

FAKULTAS HUKUM UMSU
Perkawinan Sejenis Dalam...(Otong Syuhada)

Volume 4 Nomor 1, Januari-Juni 2019, 87-102 DOI: https://doi.org/10.30596/dll.v4i1.3168

(LGBT) (Maneger Nasution, 2018).

Posisi hukum Perkawinan sesama jenis di Indonesia tidak diakui bukan karena landasan hak asasi manusia yang tidak terbatas, tetapi dibatasi oleh norma agama. Lesbian, Gay, Biseksual danTranseksual (LGBT) sejatinya bukanlah hak asasi, melainkan penyakit. Karena itu jangan ditolerir, tapi harus diobati. Bukannya melegalkan keinginan mereka, tetapi berupaya mengarahkan orientasi seksual yang merupakan penyimpangan terhadap ajaran agama dan kodrat manusia.

Kelompok LGBT di bawah payung 'Hak Asasi Manusia' meminta masyarakat dan Negara untuk mengakui keberadaan komunitas ini, bila melihat dari Konstitusi Indonesia yakni Undang-Undang Dasar 1945 Pasal 28 J yang menyatakan sebagai berikut :

a. Setiap orang wajib menghormati hak asasi manusia orang lain dalam tertib kehidupan bermasyarakat, berbangsa, dan bernegara.

b. Dalam menjalankan hak dan kebebasannya, setiap orang wajib tunduk kepada pembatasan yang ditetapkan dengan undang-undang dengan maksud semata-mata untuk menjamin pengakuan serta penghormatan atas hak dan kebebasan orang lain dan untuk memenuhi tuntutan yang adil sesuai dengan pertimbangan moral, nilai-nilai agama, keamanan, dan ketertiban umum dalam suatu masyarakat demokratis.

Di dalam konstiusi Indonesia memandang HAM memiliki batasan, dalam menjalankan hak dan kebebasannya setiap orang wajib tunduk pada undang-undang, dimana batasanya adalah tidak boleh bertentangan dengan moral, nilai-nilai agama, keamanan dan ketertiban umum; Indonesia memang bukan Negara yang berdasarkan agama namun Pancasila jelas menyatakan dalam sila pertamanya 'Ketuhanan Yang Maha Esa' sehingga nilai-nilai agama menjadi penjaga sendi-sendi konstitusi dalam mewujudkan kehidupan demokratis bangsa Indonesia.

Begitu juga ditegaskan pula dalam Undang-Undang Nomor 39 tahun 1999 tentang Hak Asasi Manusia Pasal 70 yang menyatakan sebagai berikut "Dalam menjalankan hak dan kebebasannya, setiap orang wajib tunduk kepada pembatasan yang ditetapkan oleh undangundang dengan maksud untuk menjamin pengakuan serta penghormatan atas hak dan kebebasan orang lain dan untuk memenuhi tuntutan yang adil sesuai dengan pertimbangan moral, keamanan, dan ketertiban umum dalam suatu masyarakat demokratis", dan Pasal 73 Undang-Undang Nomor 39 tahun 1999 tentang Hak Asasi Manusia yang menyatakan "Hak dan kebebasan yang diatur dalam undang-undang ini hanya dapat dibatasi oleh dan berdasarkan undang-undang, semata-mata untuk menjamin pengakuan dan penghormatan terhadap hak asasi manusia serta kebebasan dasar orang lain, kesusilaan, ketertiban umum, dan kepentingan bangsa”. Pembatasan-pembatasan HAM memungkinkan demi penghormatan kepada hak asasi manusia oleh karenanya Negara hadir dalam melakukan batasan-batasan tersebut untuk kepentingan bangsa.

Mengingat Indonesia memang tidak memiliki celah hukum untuk pelegalan Perkawinan sejenis tersebut dan ini di atur secara tegas oleh konstitusi kita yaitu Undang-Undang Dasar 1945 begitu juga halnya falsafah negara kita yaitu Pancasila di sila Ketuhanan Yang Maha 
Jurnal Ilmu Hukum

FAKULTAS HUKUM UMSU
Perkawinan Sejenis Dalam...(Otong Syuhada)

Volume 4 Nomor 1, Januari-Juni 2019, 87-102 DOI: https://doi.org/10.30596/dll.v4i1.3168

Esa, maka sudah seharusnya segala aspek kehidupan berbangsa dan bernegara haruslah berlandaskan ketuhanan yang maha esa. Ini berarti jika ingin melegalkan Perkawinan sejenis maka kita harus mengubah UU Perkawinan yang telah ada dan yang sangat di cintai oleh rakyat Indonesia, terbukti ketika ada pihak yang menguji pasal serupa yaitu Pasal 1 UndangUndang Nomor 1 Tahun 1974 tentang Perkawinan yang kemudian menimbulkan gejolak di tengah-tengah masyarakat hingga akhirnya Mahkamah Konstitusi memutuskan bahwa pasal tersebut tidak bertentangan dengan konstitusi Indonesia, itu artinya ketika negara memberikan status pelegalan untuk Lesbi Gay Biseksual dan Transgender (LGBT) maka pemerintah akan berhadapan dengan massa yang jauh lebih besar yaitu rakyat Indonesia sendiri.

Belum lagi jika hal ini terjadi maka kita harus mengubah Pancasila yang merupakan ideologi bangsa dan juga konstitusi kita UUD 1945. Maka sungguh sebenarnya hal ini tidak memiliki tingkat keurgenan yang sesungguhnya karena pada hakikatnya tidak ada pihak yang di diskriminasi dan juga dilanggar haknya termasuk Lesbi Gay Biseksual dan Transgender (LGBT), ini dikarenakan hukum yang sesungguhnya ialah hukum yang dibentuk sesuai dengan keinginan masyarakat banyak maka selama kaum minoritas tidak dikesampingkan haknya maka mereka harus tunduk dan patuh terhadap hukum yang berlaku (Dakwatuna, 2018). Jika dikaitkan dengan teori progresifyang menyatakan pemikiran hukum perlu kembali pada filosofis dasarnya, yaitu hukum untuk manusia.

Dengan filosofis tersebut, maka manusia menjadi penentu dan titik orientasi hukum. Hukum bertugas melayani manusia, bukan sebaliknya. Oleh karena itu, hukum itu bukan merupakan institusi yang lepas dari kepentingan manusia. Mutu hukum ditentukan oleh kemampuannya untuk mengabdi pada kesejahteraan manusia yang berpancasilais bukan untuk mengabdi pada sekelompok orang yang prilakunya bertentangan dengan Pancasila termasuk perkawinan sejenis dalam artian bahwa perkawinan sejenis telah melanggar tatanan kehidupan berbangsa dan bernegara yang berideologikan Pancasila.

\section{KESIMPULAN DAN SARAN Kesimpulan}

Setiap Individu yang ingin melakukan Perkawinan Sesama Jenis jika dikaitkan dengan Aliran Eksistensialisme tidak merupakan sebuah pelanggaran dan Kebebasan menjadi semacam kutukan yang melekat pada diri manusia, maka setiap individu yang akan melakukan perkawinan termasuk perkawinan sejenis diberikan kebebasan sebesarbesarnya,namun perkawinan sejenis itu bila ditinjau dari teori hukum progresif dan tujuan hukum secara sosiologi perbuatan perkawinan sejenis bertentangan dengan nilai-nilai yang hidup ditengah-tengah masyarakat dan agama yang dianut di Negara kita. DUHAM PBB merupakan perangkat hukum internasional yang bertindak sebagai payung dalam bidang HAM. Namun Indonesia tidak dapat memberlakukan Perkawinan sesama jenis ke dalam bentuk regulasi. Sebab, Perkawinan sesama jenis bertentangan dengan ideologi negara, Pancasila, dan konstitusi Indonesia. Konstitusi Indonesia menganut asas Ketuhanan Yang Maha. Sebagai bangsa beragama, sudah sejatinya menolak Perkawinan sesama jenis karena 
Jurnal Ilmu Hukum FAKULTAS HUKUM UMSU
Perkawinan Sejenis Dalam...(Otong Syuhada)

Volume 4 Nomor 1, Januari-Juni 2019, 87-102 DOI: https://doi.org/10.30596/dll.v4i1.3168

perilaku menyimpang itu bertentangan dengan ajaran agama manapun yang ada di Indonesia.

\section{Saran}

Setiap manusia bebas melakukan sesuatu sesuai dengan keingginanya, namun kebebasan manusia itu harus dibatasi dengan peraturan perundang-undangan agar tidak berbenturan dengan orang lain begitu pula dengan perkawinan sejenis harus berlandaskan kepada tuntunan agama dan Negara serta Negara Indonesia harus membuat peraturan khusus yang mengatur masalah perkawianan sejenis. DUHAM PBB dalam pelaksanaannya bergantung pada hukum nasional suatu negara karena hukum yang paling mengikat adalah hukum nasional. Negara Indonesia adalah Negara hukum Pancasila dan Bangsa Indonesia adalah bangsa yang beragama, yang sudah sepatutnya perkawinan sejenis tidak boleh tumbuh dan berkembang di Negara Indonesia. Oleh karena NegaraIndonesia harus membuat sanksi yang tegas bagi pelaksanaan perkawinan sejenis. 
Jurnal Ilmu Hukum

FAKULTAS HUKUM UMSU
Perkawinan Sejenis Dalam...(Otong Syuhada)

Volume 4 Nomor 1, Januari-Juni 2019, 87-102 DOI: https://doi.org/10.30596/dll.v4i1.3168

\section{DAFTAR PUSTAKA}

Baehr, Peter R. (2001). Human Rights Universality in Practice. London: Palgrave.

Beerling, R.F. (1966). Filsafat Dewasa Ini. Djakarta: Balai Pustaka.

Cahyadi, Antonius., \& E. Fernando M. Manullang. (2008). Pengantar ke Filsafat Hukum. Jakarta: Kencana.

Dagun, Save M. (1990) . Filsafat Eksistensialisme. Jakarta:Rineka Cipta.

Departemen Pendidikan dan Kebudayaan. (1987). Kamus Besar Bahasa Indonesia. Jakarta: Cet. Ke-1Balai Pustaka.

Kartono, Kartini. (2007). Patologin Sosial Jilid I. Jakarta: RajaGrafindo Persada.

Kurzman, Charles. (2003). Wacana Islam Liberal: Pemikiran Islam Kontemporer tentang Isuisu Glogal, terj. Bahrul Ulum dan Heri Junaidi. Jakarta: Paramadina.

Kusuma, Mahmud. (2009). Menyelami Semangat Hukum Progresif; Terapi Paradigmatik Atas Lemahnya Penegakan Hukum Indonesia. Yogyakarta: Antony Lib bekerjasama LSHP.

Ramali, Ahmad. (2012). Memelihara Kesehatan dalam Hukum Islam. Jakarta: Balai Pustaka.

Rapar, Jan Hendrik. (2010). Pengantar Filsafat. Yogyakarta: Cet. Ke-14, Kanisius.

Sidharta, B. Arief. (2008). Apakah Filsafat dan Filsafat Ilmu Itu?. Bandung: Pustaka Sutra.

Soekanto, Soerjono., \& Mamudji, Sri. (2003). Penelitian Hukum Normati fSuatu Tinjauan Singkat. Jakarta: RajaGrafindoPersada.

Soekanto, Soerjono., \& Mamudji, Sri. (1981). Pengantar Penelitian Hukum. Universitas Indonesia. Press.

Soekanto, Soerjono., \& Mamudji, Sri. 2007. Sosiologi Suatu Pengantar. Jakarta: RajaGrafindo Persada.

Soemitro, Ronny Hanitijo. (1990). Metodologi Penelitian Hukum dan Jurimetri. Jakarta: Ghalia Indonesia.

Tafsir, Ahmad. (1992). Filsafat Umum: Akal dan Hati Sejak Thales sampai James. Bandung: PT. Remaja Rosda Karya,

Theo C. Van Boven. (1982). Distinguishing Criteria of Human Rights, in Karel Vasak, ed., The International Dimensions of Human Rights, Westport. Conn: Greenwood Press fo UNESCO.

Christianto, Hwian. (2015). Eksistensi Hak Atas Materi Pornografi Berdasarkan Norma Kesusilaan. Jurnal Veritas et Justitia. Volume 1. No. 1. Juni,

Erwinsyahbana, Tengku. (2012). Perspektif Hukum Perkawinan Antar Agama yang Berkeadilan Dikaitkan dengan Politik Hukum Perkawinan Indonesia dalam Rangka Pembangunan Hukum Keluarga Nasional. (Disertasi. Fakultas Hukum Program Doktor Ilmu Hukum Pascasarjana Universitas Padjadjaran, Bandung).

Sugiarto, Ahmad. (2018). Hubungan Antara Sila-Sila Pancasila. Diakses pada tanggal 27 November 2018 melalui http://pend-pancasila. blogspot. com. 
Dakwatuna. (2018). Apakah Negara Melanggar HAM Jika Tidak Melegalkan Perkawinan Sejenis? Diakses pada tanngal 3 Desember 2018 melalui https://www.dakwatuna.com/2015/.

Wibowo, Falazuardika Imantara. (2018). Filsafat Eksistensialisme \& Fenomenologi. Diakses tanggal 28 November 2018 melalui http://falazuardika.blogspot.com.

Laksono, Khairudin Aji. (2018). Perkawinan Sesama Jenis: Antara Penegakan HAM dan Ajaran Agama. Diakses pada tanggal 2 Desember https://anfieldvillage. wordpress.com

Nasution, Maneger. (2018). Perkawinan Sesama Jenis Perspektif HAM Yang Adil Dan Beradab. Diakses pada tanggal 26 November 2018 melalui https://rmol.co/read.

Maneger Nasution, "Perspektif HAM Perkawinan Sesama Jenis". https://www. republika.co.id Diakses Tanggal 20 November 2018.

Masduri. (2018). Masa Depan Kita Dan LGBT. Diakses pada tanggal 2 Desember 2018 melalui http:// kotakata.id

Tamtam, Tamy. (2018). Eksistensi Perkawinan Sejenis Ditinjau Dari Aliran Eksistensialisme. Diakses pada tanggal 1 Desember 2018 melalui http://www.academia.edu. 